\title{
Malignant Major Salivary Gland Neoplasm
}

National Cancer Institute

\section{Source}

National Cancer Institute. Malignant Major Salivary Gland Neoplasm. NCI Thesaurus.

Code C4762.

A primary or metastatic malignant neoplasm affecting the major salivary glands.

Representative examples include carcinoma, lymphoma, and sarcoma. 